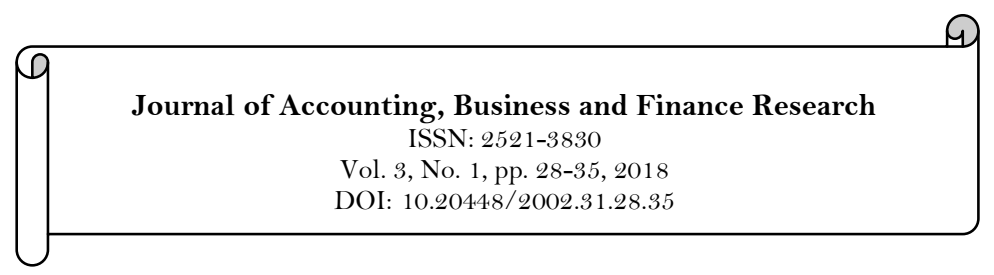

\title{
Creative Economy to Increase Community Revenue Based on Tourism Object, Medalsari Village, Pangkalan District Karawang Regency
}

\author{
Budi Rismayadi ${ }^{1}$ \\ Mumun Maemunah ${ }^{2}$ \\ 1,2 University of Buana Perjuangan Karawang, Indonesia.
}

\begin{tabular}{l|l} 
Abstract & \\
The important role of counselling and training activities for the & Keywords: \\
community on improving community skills that can be used to & $\begin{array}{l}\text { Counseling } \\
\text { Resources } \\
\text { improve the quality of life and welfare by utilizing the resources and }\end{array}$ \\
potential in the villages is the goal to be achieved. Through & Jecony. \\
counselling and training activities, community get information and & JEL Classification: \\
insight, so people can understand deeply about the creative economy & M2, Z32. \\
and its benefits. The material of the counselling delivered is adjusted & Licensed: \\
to the potential of resources in the village. Counselling materials & This work is licensed under a \\
include the understanding of what is the meant of creative economy & Creative Commons Attribution \\
including creative industry and its definition, including what is & 4.0 License. \\
creativity, how to utilize local raw materials that can be processed & Publisher: \\
into products, processing of natural materials into decorative & Scientific Publishing Institute \\
products, processed food products from the forest product, packaging & \\
techniques and marketing of agricultural and forestry products, & \\
Medalsari village is quite famous as a village that has a natural & \\
attractions waterfall. Counselling activities for strengthening the & \\
creative economy based on village resources was followed by fifty & \\
participants could give benefit to the participants and expected to & \\
provide motivation to other communities. This could be seen from & \\
the enthusiasm of the participants in counselling and question- & \\
answering. It also appears that the participants feel motivated to & \\
develop their business creativity, as well as participants who only & \\
rely on their work as farmers, breeders and gardeners seem quite & \\
interested in trying to start developing their creative business. &
\end{tabular}

\section{Introduction}

Karawang regency with an area of $1,753.27 \mathrm{~km}^{2}$ or 3.73 percent of West Java Province, Karawang is one of the areas that have fertile land in West Java, so most of the land is used for wetland farming with an area of 97,529 hectares, and for plantation covering an area of 7,798 hectares. The shape of the soil in Karawang regency mostly in the form of a relatively flat plain with variations between $0-5 \mathrm{~m}$ above sea level. Only a small part of the region is bumpy and hilly with a height between 0-1200 $\mathrm{m}$ above sea level.

Southern region of Karawang regency mostly forest and hill areas with different geographical conditions with most of Karawang area, the south area is relatively hilly and has Sanggabuana mount and the plateau is relatively higher.

The southern region has the forestry potential with the dominance of plantations and crops, the community relies on forest products as addition to the incomes of the community, the effort to develop the natural resources potentials utilized with the ultimate goal of development is for the welfare of the surrounding communities.

While the tendency of environmental damage is often caused by the development that has been applied not in accordance with the principles of sustainable development. Therefore, participatory development is very important to improve the economy of local communities. Particularly to achieve the objectives of management of mountainous area resources in an integrated and sustainable way, it is necessary to balance management with multidimensional such as ecology dimension, social dimension, economic dimension, inter sectorial, discipline and all stakeholders. 
Based on community registration in 2016 from the Central Bureau of Statistics (BPS) Karawang that the population of Karawang regency as much as 2,295,778 people consisting of 1,177,310 male or reach the most composition to reach $51.31 \%$ and the number of female as much as $1,118,468$ with a composition of $48.69 \%$, with sex ratio reaching 105.36. While the average density reached 1 ,094 people per $\mathrm{Km}^{2}$. The most densely populated area is Karawang Barat district with a population of 4,932 people per $\mathrm{Km}^{2}$, while the lowest density kecamatan is Pakisjaya district with an average population of 382 people per $\mathrm{Km}^{2}$.

Besides, the composition of the population can also be seen by grouping the population into productive age (15-64 years old), unrepresented age $(<15$ years) and no more productive age ( $>65$ years) productive age population is capital in the implementation of development in all sectors, with the expectation of productivity and effectiveness that occur is also supported by adequate facilities and infrastructure, where humans become the goal of the implementation of development itself.

Productive age population in Karawang regency in 2015 reached 1,555,595 people or equal to $68.42 \%$. While the unrepresented population reached 614.086 or $27.01 \%$ and the unproductive population of 103,898 people or $4.57 \%$ thus the dependency ratio of age less than 15 years and population aged more than 65 years reached $46.15 \%$ which means that every 100 people of productive age bear 46 unrepresented and unproductive age which is about $51,61 \%$ the rest are $48,39 \%$ productive population from men.

The population distribution in Karawang regency remains cantered in the central region, because the economic sector is still also cantered in the region. Areas that are traversed or adjacent to tolls or railway infrastructure / infrastructures, have higher population densities, such as Karawang Barat, East Karawang, Telukjambe Timur, Klari and Cikampek Sub-district when compared to others sub-districts.

Table-1. The population of Karawang regency According to District And Gender in 2016.

\begin{tabular}{|c|c|c|c|c|}
\hline No & District & Male & Female & Total \\
\hline 1 & PANGKALAN & 19.249 & 18.781 & 38.030 \\
\hline 2 & TEGALWARU & 18.941 & 17.909 & 36.850 \\
\hline 3 & CIAMPEL & 20.975 & 21.480 & 42.455 \\
\hline 4 & TELUKJAMBE TIMUR & 71.867 & 64.726 & 136.593 \\
\hline 5 & TELUKJAMBE BARAT & 26.178 & 25.476 & 52.654 \\
\hline 6 & KLARI & 84.945 & 82.666 & 167.611 \\
\hline 7 & CIKAMPEK & 59.040 & 56.431 & 115.471 \\
\hline 8 & PURWASARI & 34.510 & 33.765 & 68.275 \\
\hline 9 & TIRTAMULYA & 24.319 & 23.452 & 47.771 \\
\hline 10 & JATISARI & 39.682 & 38.008 & 77.690 \\
\hline 11 & BANYUSARI & 28.038 & 27.003 & 55.041 \\
\hline 12 & KOTABARU & 66.080 & 63.083 & 129.163 \\
\hline 13 & CILAMAYA WETAN & 41.970 & 39.291 & 81.261 \\
\hline 14 & CILAMAYA KULON & 33.203 & 31.295 & 64.498 \\
\hline 15 & LEMAHABANG & 33.602 & 31.953 & 65.555 \\
\hline 16 & TELAGASARI & 33.514 & 31.396 & 64.910 \\
\hline 17 & MAJALAYA & 24.367 & 23.123 & 47.490 \\
\hline 18 & KARAWANG TIMUR & 66.162 & 61.145 & 127.307 \\
\hline 19 & KARAWANG BARAT & 85.784 & 81.965 & 167.749 \\
\hline 20 & RAWAMERTA & 27.045 & 25.452 & 52.497 \\
\hline 21 & TEMPURAN & 32.601 & 30.632 & 63.233 \\
\hline 22 & KUTAWALUYA & 30.185 & 27.794 & 57.979 \\
\hline 23 & RENGASDENGKLOK & 57.737 & 55.008 & 112.745 \\
\hline 24 & JAYAKERTA & 33.589 & 31.066 & 64.655 \\
\hline 25 & PEDES & 39.057 & 36.648 & 75.705 \\
\hline 26 & CILEBAR & 22.045 & 20.864 & 42.531 \\
\hline 27 & CIBUAYA & 26.909 & 25.593 & 52.502 \\
\hline 28 & TIRTAJAYA & 34.185 & 32.623 & 66.808 \\
\hline 29 & BATUJAYA & 40.719 & 40.575 & 81.294 \\
\hline 30 & PAKISJAYA & 19.812 & 19.643 & 39.455 \\
\hline \multicolumn{2}{|c|}{ Total } & 1.177 .310 & 1.118 .468 & 2.295 .778 \\
\hline
\end{tabular}

It is well known in Table 1 that the high number of population at productive age is a potential that can support the progress and sustainability of regional development if it can be maximally empowered.

An area with abundant natural resource potential and supported by productive quality of human resources and able to provide employment that can absorb productive workforce in the area of course will be able to 
increase the development of the region faster, of course, regional development policies and the objectives to be achieved by the region are emphasized on the purpose, the most important aspect for the region is how to improve the quality of the population.

The livelihood of Karawang community is divided into agriculture, trade and marine sector spread in the north and south and some of the eastern, central and western part of Karawang regency are mostly workers either in the local government or private sector or in several industrial areas, livelihood Karawang community is still dominated by agrarian sector that is on agriculture sector, plantation, livestock, marine and fishery.

In order to sustain the livelihood of households, sustainable economic opportunities should be sought by utilizing the potential of surrounding natural resources. The concept of sustainable livelihood begins with a desire to empower the capacity of people in need of current income and future socio-economic needs and minimize their vulnerability to stress and shock (Ashley \& Carney, 1999).

In accordance with the concept, the natural resources contained in Karawang regency if it can be utilized and managed using the principles of sustainability and applying the concept of creative economy is expected to have an impact on improving the welfare of households in addition also have alternative and sustainable livelihoods, especially for people who included in the poor category.

The southern part of Karawang regency covers 4 districts namely Tegalwaru, Pangkalan, Telukjambe Barat and Ciampel in the southern part is generally a hilly area and has forest area, although the southern part of Telukjambe Barat and Ciampel is industrial area, Industrial Area KIIC operate as many 78 companies, Industrial Kawasan Industri Mitra (KIM) operate as many as 19 companies, Industrial Area Surya Cipta (KISC) operate as many as 50 companies, Industrial Area Indotaisei operate as many as 23 companies, thus the number of existing plants in the southern part of Karawang as many as 170 factories.

Pangkalan district has 8 villages with total area reaching $73.65 \mathrm{Km}^{2}$ and population potential with total reaching as many as 38,030 people which consist of number of male population 19.249 people and number of female population 18,781 inhabitants.

This research will be conducted in Pangkalan district in Medalsari village which is the most end of village which directly border area with Bogor regency with wide of village area reaching $9.93 \mathrm{Km} 2$. Area of rice field reaches $3,74 \mathrm{~km}^{2}$, plantation area $1.73 \mathrm{Km}^{2}$, wide of $0,31 \mathrm{~km}^{2}$ and land area or land pond $0,33 \mathrm{Km}^{2}$, with population 3,773 people with male population 1,836 and female population 1937 inhabitants.

In addition Medalsari village has seven mining business units of natural stone mining business, and 27 excavation business units involving 11 families doing the business. Small and medium enterprises in medalsari village as many as 4 units of UMKM business, and has 1 local tourism attraction whose existence is still not included in the data of tourist attraction in the Pangkalan District.

Medalsari village has considerable natural resource potential that can be used to improve the welfare of the local community, however, because of the constraints of knowledge and skills are needed creative ideas from the community in the utilization of limited resources.

The idea of creative ideas can be poured in the form of creative products that can improve welfare. According to economist (Paul, 1993) the idea is a very important economic item, more important than the object emphasized in most economic models. In a world with this physical limitation, the discovery of great ideas coincides with the discovery of millions of small idea ideas that keep the economy growing. Ideas are the instructions that make us combine physical resources that are limited to being more valuable.

Then Toffler (1980) in his theory to divide the wave of economic civilization into three waves. The first wave was the wave of agricultural economy. Second, the wave of the industrial economy. Third is the wave of information economy.

Then predicted the fourth wave which is the wave of creative economy with the orientation of creative ideas and ideas. Romer also argues that a country is poor because its people have no access to the ideas used in the national industry to generate economic value.

Compiled a development plan in confront of competition in the creative economy divided into 14 sectors: advertising, architecture, art, craft, design, fashion, film and photography, interactive games, music, performing arts, and printing, computer services, radio and television (Simatupang, 2008). In its development, there is the addition of several industrial sectors as an incubator of creative industries that is agribusiness, culinary, and automotive. In the implementation of small and medium industries many dominate and move the creative industry.

The growth of the creative industry in Indonesia is caused to the prolonged global crisis that gives rise to a deeper spirit of creating and innovating things in creating new ideas and works.

The growth of creative industry in Indonesia has not been able to give a positive and significant impact for Indonesia, one of the causes is "problem management" which is a thought that leads to the idea that a product is produced only for consumption in the country so that this causes that Indonesia is included in the categorization as an internationally potential consumptive country.

In its development based on data from statistics and creative economic survey results of cooperation between creative economic agencies and statistical centre of Indonesia (BPS) in 2016 are known that the creative economy of Indonesia contributed 7.38 percent of the total national economy, there are three leading subsectors that contribute large enough from the culinary, fashion and craft subsector, and by 2015 there are 
four sub sectors that also dominate the creative economy in Indonesia namely Communication and Visual Design, Music, Video Animation and Architecture.

Limited educational facilities for rural communities with only 4 elementary school facilities with low community participation rates compared to other villages, access to information is relatively limited, making it difficult for community to obtain information, but this does not mean they have no idea creative ideas to improve their family's economy, but they are not yet highly motivated to develop these creative ideas and the lack of access to information, technology, skills training and network marketing of their business results. Therefore it is necessary to conduct counselling and training, especially to the village community to increase knowledge on how to develop creative ideas into creative economic resources that can increase the income and welfare of the community.

\section{Literature Review}

The current technological and scientific developments have an enormous impact on additional information that can serve as a guide for everyone in their goal of improving the quality of life, one of which is to increase creativity in the various fields desired.

The development of information technology is also able to provide insight and innovation so encourage everyone to be able to improve activity and creativity in producing various findings and products of innovation, the process of production to product development, this becomes one of the factors that make the importance of knowledge about creative economy by everyone.

Creative economy can be used as one solution in facing the level of competitive competition, so the level of competition is not only determined by how much process level of production process done but also aspects of creativity and innovation began to play a very important role in addition to technology factors provide a strong influence on the development of creative economy.

Aisah, Irwan, and Ainul (2014) from the results of the research conducted in Batu City in 2014 stated that the development of creative industries is need of innovative human resources and high creativity. The results showed that the development of creative industries in handicraft sector can improve the welfare of the community.

Creativity industry players can improve product output to be better so have high selling value.

Enhancement of creativity of creative economic entrepreneurs in industry must be supported by local government through training activities, debriefing and continuous supervision. The supporting aspects that lead to an increase in creative industry development are the role of local government, the quality of resources, and the potential of resources owned by the region itself.

The results of the research that conducted by Andri (2015) concluded that the creative economy can be used as one solution for the welfare of society because in the creative economy system gives the added value either to the industry itself or to its human resources.

The existence of a creative economy has a positive impact on reducing the unemployment rate and will increase the level of the economy.

Our thinking on how to improve people's welfare through creative economy is believed to contribute significantly to the nation's economy. Indonesia began to see that the various sub-sectors in the creative industry have the potential to be developed because Indonesia is rich with the resources of creative people and the nation's cultural heritage that is very diverse and abundant throughout the archipelago in Indonesia.

The important role of the growing creative economy in Indonesia has been proven after the economic crisis that attack in the era of 1990 s until 2000, it turns out the creative economy can survive and even able to sustain economic activity of Indonesia very well, and this is believed will be able to answer fundamental economic problems in the purpose of promoting economic growth in Indonesia, able to provide employment for the community, thus reducing the open unemployment rate in Indonesia, able to provide additional income and increase the purchasing level of the community so it is expected to reduce the poverty rate of the community.

In the era of creativity when it comes to advance we must complement our high-tech capabilities, with the desire to achieve high-concept and high-touch levels.

High-concept is the ability to create artistic and emotional beauty, recognize patterns and opportunities, create beautiful narratives and produce discoveries that others have not realized. High-touch is the ability to empathize, understand the essence of human interaction and find meaning.

\section{Method of Research}

\subsection{Target}

The target of this counselling activity is the people of Medalsari Village District Pangkalan Karawang regency consisting of 50 people who are interested in the development of creative economy in the village.

The expected outcomes of this activity are:

1. The community becomes motivated and more confident to develop and realize creative ideas.

2. The public understands the importance of developing creative economy to increase the family income and the village economy. 
3. Development of creative economic activities in the village to support development in Medalsari Village.

4. Establishment of village institutions that support the development of creative economy in Medalsari village.

This activity was held in Medalsari Village, Pangkalan district, Karawang Regency, West Java Province. The implementation of this activity is carried out for 3 (three) months from March to May 2018 consisting of several stages as follows:

1. Preparing materials or materials that is needed in counselling strengthening the creative economy based on village resources for the community Medalsari Village, Pangkalan District, Karawang regency.

2. Held a meeting of fellow team counselling to discuss the material activities to be carried out and the division of tasks between the implementing teams.

3. Conducted a meeting with the Head of Medalsari Village, Pangkalan District, Karawang Regency, in order to get the implementation permit and schedule of activities.

4. Conducting counselling on strengthening the creative economy based on village resources in Medalsari Village, Pangkalan District, Karawang Regency.

\section{Results and Discussion}

This activity is held in cooperation with the community and government officials Medalsari Village, Pangkalan District, Karawang regency and assisted by some students UBP Karawang 2015. This counselling activity is one of the important stages of research activities and community service as part of College of Tridarma.

The activity was conducted in Medalsari Village Office Hall, Pangkalan District, Karawang Regency. The opening in this counseling is by the secretary of sub-district of Pangkalan District. As for the material of this counseling activity are:

1. Understanding the Creative Economy and the types of Creative Industries that can be developed in rural areas based on the potential of local resources.

2. Financial Management of Rural Creative Industries.

3. Production Management and Creative Industry Marketing.

The speakers in this activity are lecturer of Management Program Faculty of Business and Social Sciences University of Buana Perjuangan Karawang. In addition to giving lectures on the counselling, the speakers also distributed creative business brochures. The activities went smoothly and the participants followed the activities with enthusiasm and excitement.

The initial stage before the implementation of counselling activities and the delivery of material activities in advance carried out the initial questioning to all 50 participants before the implementation of the activities of all answers given by participants then tabulated and made conclusions of each answer, so that can be presented data on the conclusions of the answers submitted by the participants are arranged in the table as follows:

Table-2. Participant's Answers before the Implementation of Counselling and Giving of Materials.

\begin{tabular}{l|l|l}
\hline No & Questions & Participant's answer Conclusion \\
\hline 1 & $\begin{array}{l}\text { Do Medalsari people know and understand } \\
\text { about creative economy? }\end{array}$ & $\begin{array}{l}\text { Most of the participating communities do not know } \\
\text { and understand what is meant by creative economy, } \\
\text { they mostly understand about trade economy, } \\
\text { production and marketing. Most of them are more } \\
\text { familiar with cooperative economy. }\end{array}$ \\
\hline 2 & $\begin{array}{l}\text { Have Medalsari people ever received } \\
\text { counselling on the creative economy? }\end{array}$ & $\begin{array}{l}\text { Most of the participants stated that they had never } \\
\text { received and attended counselling and training on } \\
\text { the creative economy before. }\end{array}$ \\
\hline 3 & $\begin{array}{l}\text { Have Medalsari people ever seek information } \\
\text { about the creative economy? }\end{array}$ & $\begin{array}{l}\text { All participants said they had never sought } \\
\text { information about the creative economy. }\end{array}$ \\
\hline 4 & $\begin{array}{l}\text { Have Medalsari people ever accessed } \\
\text { information in the form of videos related to } \\
\text { the creative economy? }\end{array}$ & $\begin{array}{l}\text { Most participants said they never accessed videos } \\
\text { related to information about creative economic } \\
\text { activities, the reason being that they did not } \\
\text { understand how important the information was to } \\
\text { them. }\end{array}$ \\
\hline Source: Researcher 2018, processed.
\end{tabular}

From the above Table 2 it is known that Medalsari people have not received information about the creative economy, what sectors are included in the creative economy and how they should start in the creative economy. 
This indicates that the community has not been able to access and receive information about the importance of economic activities especially related to the creative economy, another problem is alleged that the community actually has done activities related to their business but not yet understand correctly about the definition and criteria referred to in economic activities creative.

In the implementation of this counselling activity was attended by various layers of society. Community leaders who were present were Head of Pangkalan District and his Secretary, Head of. Medalsari village, and all RT officials and RW officers.

In addition to community leaders were also attended by youth organization leaders, heads of business groups, as well as small and medium entrepreneurs.

The attendees seemed very enthusiastic about listening to the counselling delivered, it is shown by the many people who asked and wanted to get a deeper explanation of how the creative economy can be developed in their village area.

The six-hour counseling material is divided into three material sessions with three speakers. In counselling, participants are invited to observe the importance of creative economic activity for the community. They are also invited to view and observe videos about creative economic activities from various regions, some examples of sectors of the creative economy are shown to the public among others culinary sector, fashion sector and craft industry.

As a concrete manifestation of this devotional activity as the outcome is build on "Rumah Kreasi" cooperation with the community and UBP Karawang. Legally, the establishment of "Rumah Kreasi" was inaugurated by the Head of Pangkalan District, Karawang regency. Furthermore, all the management that has been made the decision letter was inaugurated by the head of the district.

The community hope the Rumah Kreasi (Creative House) can be useful for the long term so they really need guidance from the competent parties. Counselling activities are conducted by lecture, question-answer method and showcasing the films of manufacturing process of various creative industry products that are various handicraft products from local raw materials produced by rural communities from other regions. The screening of the film also intends to motivate people's desire to develop their own creative ideas to utilize the resources available in their region.

Potential resources Medalsari village is very diverse and prospects developed to support the creative community's economic stretch, moreover Medalsari village has a natural tourist attraction that is waterfall, Grand Canyon Medalsari, which is usually on the day visited by many tourists rom Karawang and from outside Karawang.

Resources that can support the creative economy of the community include agricultural resources of rice and palawija, forest and mining resources, forest mountain tourism, customary resources. Medalsari village was once one of the most attractive gem-producing villages, but the effort was no longer continued due to collision with permits and environmental damage caused by the mine.

Medalsari village also has a very interesting place to be developed as an effort to improve the welfare, because the area is directly adjacent to Bogor regency so as to enable access to information and the reach of marketing can be more broadly. The most important resource that is owned is the village's human resources for the development of creative economy.

The counselling delivered material is adapted to the potential of resources in the village. Counselling materials include the understanding of what is meant by the creative economy and its definition, including what it is creativity, how to utilize local raw materials so that can be processed into products, packaging process and marketing of forest products that have been produced by the people, the utilization of forest products into handicraft products, processed food products from forest products, management of the Grand Canyon waterfall tourist attraction and its marketing to attract visitors.

The community grew faster and more interested in counselling until the end. This counselling activity is also published in local mass media. Implementation of counselling given to the community is an appropriate step to motivate the community's business interests.

After the implementation of the counselling activity is completed and then distributed the quiz to see how the participants' responses about the activities, the tabulation of the participants' answers is organized as follows.

The obstacles faced in this counselling activity is the difficulty of adjusting the schedule because most of the people are farmers and planters whose activities during the day they work in fields, besides the distance from campus to this village is relatively quite far so it takes a long time to reach this village especially in the early stages before counselling. Nevertheless, it is expected that this activity can be carried out by conducting counselling and technical trainings related to the development of creative community business that already exist. 
Table-3. Participants' answers regarding responses to counseling activities.

\begin{tabular}{|c|c|c|}
\hline No & Questions & Participant's answer Conclusion \\
\hline 1 & $\begin{array}{l}\text { How is the response of the participants to the } \\
\text { activities that have been implemented? }\end{array}$ & $\begin{array}{l}\text { All participants were satisfied with the activity of } \\
\text { creative economic counselling activities, they } \\
\text { gained enthusiasm and motivation to start trying to } \\
\text { develop their talents and interests in business } \\
\text { activities of the creative industry sector in the } \\
\text { village. }\end{array}$ \\
\hline 2 & $\begin{array}{l}\text { How is the response of the participants } \\
\text { regarding the material of this activity? }\end{array}$ & $\begin{array}{l}\text { Most of the participants gave the statement that the } \\
\text { material provided was quite easy to understand, the } \\
\text { video showing of examples of creative economic } \\
\text { activity in other areas was quite well responses, the } \\
\text { participants were eager to make the same video for } \\
\text { creative economic activities in their area. Some } \\
\text { participants stated that the module given to the } \\
\text { participants should also be attached with pictures } \\
\text { and sample photos and how to make the product. }\end{array}$ \\
\hline 3 & $\begin{array}{l}\text { What is the response of participants about the } \\
\text { informants of this activity? }\end{array}$ & $\begin{array}{l}\text { Participants assess the informants of this activity is } \\
\text { good enough and quite master the material, can } \\
\text { provide inspiration and motivation to the } \\
\text { participants and use of easy language to understand. }\end{array}$ \\
\hline 4 & $\begin{array}{l}\text { What is the response of the participants } \\
\text { regarding the timing of this activity? }\end{array}$ & $\begin{array}{l}\text { Some participants stated that the activity time is } \\
\text { relatively short, they hope there is more time, and } \\
\text { the participants want to continue with the } \\
\text { assistance for one week. }\end{array}$ \\
\hline 5 & Should this activity be carried out regularly? & $\begin{array}{l}\text { Participants of the event stated that such activities } \\
\text { are carried out routinely every month, some } \\
\text { suggest to create a group of social media } \\
\text { communications for their creative industry groups. }\end{array}$ \\
\hline 6 & $\begin{array}{l}\text { What is the response of the participants } \\
\text { regarding the location of the activity? }\end{array}$ & $\begin{array}{l}\text { Participants stated that the training place is well } \\
\text { enough to be held in a government village-owned } \\
\text { building, some suggesting that it can be } \\
\text { implemented in the creative industry area in the } \\
\text { village, and some suggest a special place as an office } \\
\text { or home where the discussion of the creative } \\
\text { industry in their village. }\end{array}$ \\
\hline 7 & $\begin{array}{l}\text { What are suggestions and criticisms by the } \\
\text { participants to the committee of the event? }\end{array}$ & $\begin{array}{l}\text { Participants stated that the activity information } \\
\text { relatively urgent and short, so that they are initially } \\
\text { not ready. Moreover the next activity like this is } \\
\text { more orderly and structured. }\end{array}$ \\
\hline
\end{tabular}

\section{Conclusion}

Counselling activities to strengthen the creative economy based on the tourist attraction of Medalsari village, Pangkalan district, Karawang regency can be considered to provide great benefits especially for participants.

This is evident from the enthusiasm of participants in counseling activities and by question-answer also it appeared that the participants feel motivated to develop their business creativity, as well as those who only rely on their work as farmers and fishermen seem interested enough to try began to develop their creativity business So that, this activity needs to be done continuously. 


\section{References}

Aisah, N. F., Irwan, N., \& Ainul, H. (2014). Creative industry development in Stone Town (Study of Creative Industry of Handicraft Sector in Batu City). Journal of Public Administration of Universitas Brawijaya, 2(2), 23-34.

Andri, I. (2015). Creative economy as a welfare community solution in increasing economic level. Journal of National Seminar on Economics and Business.

Ashley, C., \& Carney, D. (1999). Sustainable livelihoods: Lessons from early experience.

Paul, M. R. (1993). Looting: The economic underworld of bankruptcy for profit. Paper presented at the In Brookings Paper on Economic Activity.

Simatupang, T. (2008). Policy analysis of creative industry development in Bandung city. Bandung: School of Business and Management, Bandung Institute of Technology.

Toffler, A. (1980). The third wave. London: Pan Books Ltd in Association with William Collins Sons \& Co. Ltd. 